\title{
Regulation of immunoreactive inhibin A and B secretion in cultured human granulosa-luteal cells by gonadotropins, activin $A$ and insulin-like growth factor type-1 receptor
}

\author{
T Vänttinen ${ }^{1}$, J Liu ${ }^{1,3}$, C Hydén-Granskog ${ }^{4}$, M Parviainen ${ }^{2}$, \\ I Penttilä ${ }^{2}$ and $\mathbf{R}$ Voutilainen ${ }^{1,3}$ \\ ${ }^{1}$ Department of Pediatrics, Kuopio University Hospital, Kuopio, Finland \\ ${ }^{2}$ Department of Clinical Chemistry, Kuopio University Hospital, Kuopio, Finland \\ ${ }^{3}$ Department of Pathology, Haartman Institute, University of Helsinki, Helsinki, Finland \\ ${ }^{4}$ Department of Obstetrics and Gynecology, Helsinki University Hospital, Helsinki, Finland \\ (Requests for offprints should be addressed to R Voutilainen, Department of Pediatrics, Kuopio University Hospital, PO Box 1777, FIN-70211 Kuopio, Finland)
}

\begin{abstract}
Inhibins are gonadal glycoproteins with endocrine effects on pituitary FSH secretion and para/autocrine effects on ovarian and testicular function. The purpose of this study was to investigate the endocrine and para/autocrine regulation of inhibin A and inhibin B secretion in human ovarian granulosa-luteal cells. The cells were obtained from women undergoing in vitro fertilization, and the primary cultures were treated with FSH, LH, human chorionic gonadotropin (hCG), activin A, 8-bromo cyclic AMP (8-BrcAMP), staurosporine (a protein kinase C inhibitor) and an antagonist of IGF action (type-1 IGF receptor antibody $\alpha \operatorname{IR} 3$ ). The secretion of inhibins was measured by ELISA assays capable of reliably distinguishing between inhibin $\mathrm{A}$ and $\mathrm{B}$.

FSH, LH, hCG and 8-BrcAMP increased inhibin A secretion on average up to $180 \% \quad(P<0 \cdot 01), 192 \%$ $(P<0 \cdot 05), 210 \%(P<0 \cdot 01)$ and $243 \%(P<0 \cdot 01)$ respectively of the control level, while their stimulatory effect on inhibin B secretion was less pronounced (up to $167 \%$,
\end{abstract}

$P<0 \cdot 01 ; 139 \%, P<0 \cdot 05 ; 127 \%, P>0 \cdot 05 ; 133 \%, P>0 \cdot 05$ of the controls respectively). $\alpha$ IR 3 decreased inhibin $\mathrm{A}$ and $\mathrm{B}$ secretion down to $70 \%(P<0 \cdot 01)$ and $50 \%(P<0 \cdot 01)$ respectively of the control. Staurosporine decreased inhibin B secretion down to $49 \%(P<0 \cdot 01)$ of the control; its effect on inhibin A secretion was not significant. Activin A increased inhibin B secretion up to fourfold of the control $(P<0 \cdot 05)$ while its effect on inhibin A secretion was insignificant.

We conclude that gonadotropins via the protein kinase A signal transduction pathway are the main positive regulators of inhibin $\mathrm{A}$ and $\mathrm{B}$ secretion in human granulosa-luteal cells. The protein kinase C signal transduction pathway seems to be important especially for inhibin B secretion. Locally produced IGFs are probably important inducers of the production of both forms of inhibin in human ovaries while activins seem to upregulate inhibin B secretion.

Journal of Endocrinology (2000) 167, 289-294

\section{Introduction}

Inhibins are dimeric glycoproteins consisting of an $\alpha$-subunit and either a $\beta A$ - (inhibin A) or $\beta \mathrm{B}$ - (inhibin B) subunit. Activins are composed of $\beta$-subunits. The homodimer of $\beta A$-subunits forms activin $A$, the homodimer of $\beta B$-subunits activin $\mathrm{B}$, and the heterodimer of $\beta A$ - and $\beta B$-subunits activin $A B$. Circulating inhibins are secreted mainly by ovaries and testes but they are also synthesized in placenta, adrenals and some gonadal tumors (reviewed in Vale et al. 1988, Ying 1988, Woodruff 1998).

The main biological function of the inhibins was originally thought to be the suppression of folliclestimulating hormone (FSH) secretion by the pituitary gland, whereas activins increase pituitary FSH secretion
(Vale et al. 1988, Ying 1988). In addition to their endocrine effects on pituitary FSH secretion, inhibin and activin peptides have important autocrine and paracrine functions in the organs in which they are produced (Mather et al. 1992, Findlay 1993, Woodruff 1998). Inhibins and activins regulate ovarian steroidogenesis in both rodents and primates (Hsueh et al. 1987, Miró \& Hillier 1992, Rabinovici et al. 1992). Inhibins may also have a role in gonadal tumorigenesis (Matzuk et al. 1992, 1996).

All inhibin subunit genes (Mason et al. 1986) are expressed in human ovaries through the menstrual cycle. The corpus luteum expresses the $\beta$ A-subunit gene, while $\beta \mathrm{B}$-subunit gene expression may be minimal or absent (Schwall et al. 1990, Roberts et al. 1993). Inhibin subunit 
peptides have been localized by immunohistochemistry in human ovaries (Yamoto et al. 1992, Arora et al. 1997). On the basis of in situ hybridization histochemistry it was assumed that inhibin B is the dominant form at the beginning of follicular development and that inhibin A becomes more important during the later stages of folliculogenesis (Schwall et al. 1990, Roberts et al. 1993). Inhibin A was recently found to be the dominant form of inhibin secreted by cultured human granulosa-luteal cells (Muttukrishna et al. 1997).

During the human menstrual cycle, serum immunoreactive inhibin concentrations follow the growth of the developing follicles, which are the main source of circulating inhibins in the follicular phase. At this stage inhibin $\mathrm{B}$ is dominant but its concentration decreases rapidly during the luteal phase. Inhibin A concentration is highest in the luteal phase, and it also decreases rapidly before the end of the cycle (Groome et al. 1996). Serum inhibin concentrations during the menstrual cycle correlate well with inhibin subunit gene expression in the corpus luteum (Schwall et al. 1990, Roberts et al. 1993).

Gonadotropin- and protein kinase C-dependent regulation of the expression of inhibin $\alpha$ and $\beta$ A subunit genes has previously been described in ovarian granulosa cells at mRNA level (Erämaa et al. 1994, Tuuri et al. 1996) but information about the inhibin peptide secretion by these cells is scant (Muttukrishna et al. 1997). The aim of the present work was to shed more light on the endocrine (FSH, luteinizing hormone (LH), human chorionic gonadotropin (hCG)) and local (activins, insulin-like growth factor (IGF) system) regulation of inhibin A and B secretion in human ovaries by using cultured granulosaluteal cells with highly sensitive and specific inhibin assays. The roles of protein kinase A- and C-dependent signal transduction pathways in inhibin secretion were tested by adding 8-bromo cyclic AMP (8-BrcAMP) (which activates protein kinase A) and staurosporine (which inhibits protein kinase $\mathrm{C}$ ) to the cell cultures.

\section{Materials and Methods}

Human ovarian granulosa cells were obtained by follicular aspiration from women taking part in in vitro fertilization programs. The study was approved by the Research Ethics Committees of Kuopio and Helsinki University Hospitals, and the women gave informed written consent. The women were treated with a gonadotropin-releasing hormone $(\mathrm{GnRH})$ analog (Synarela (Searle, Bretigny-SurOrge, France), Suprecur (Hoechst Marion Roussel, Frankfurt am Main, Germany) or Zoladex (Zeneca, Alderley Park Macclesfield, Cheshire, UK)) and an FSH preparation (Gonal-F (Serono, Bari, Italy) or Puregon (Organon, Oss, The Netherlands)) to induce the development of multiple follicles. Follicular aspiration was performed 36-38 h after hCG (Pregnyl (Organon) or Profasi (Serono)) administration. After removal of the cumulus-oocyte complex, the granulosa cells from all follicles of each woman were pooled and pelleted. The cells were then dispersed in 0.1\% hyaluronidase (Sigma Chemicals Co., St Louis, MO, USA) in Dulbecco's minimal essential medium (DMEM)-Ham's F-12 medium (GIBCO Laboratories, Grand Island, NY, USA) (1:1) for $30 \mathrm{~min}$ at $37^{\circ} \mathrm{C}$ with intermittent stirring. The granulosa cells were separated from red blood cells by centrifugation in Ficoll-Paque (Pharmacia Biotech AB, Uppsala, Sweden) for $15 \mathrm{~min}$ at $1000 \times \mathbf{g}$. The cells were then washed and plated in DMEMHam's F-12 medium (1:1) supplemented with 10\% fetal calf serum (GIBCO or Bioclear UK Ltd, Calne, Wilts, $\mathrm{UK}), 2 \mathrm{mM}$ L-glutamine, $100 \mathrm{IU} / \mathrm{ml}$ penicillin, and $100 \mu \mathrm{g} / \mathrm{ml}$ streptomycin sulfate (GIBCO) at a density of $2-5 \times 10^{5}$ cells/well on $35-\mathrm{mm}$ six-well Cellstar dishes (Greiner Labortechnik Gmbh, Frickenhausen, Germany). The cells were grown at $37^{\circ} \mathrm{C}$ in a $95 \%$ air $-5 \% \mathrm{CO}_{2}$ humidified environment and the cell culture media were changed every 2-3 days.

In vitro hormonal and other treatments were performed during the 7 th to the 11 th days of culture when the cells are the most responsive in this culture system (Voutilainen et al. 1986). The functional viability of the cells was assessed by measuring progesterone concentrations in selected culture media after different treatments. Recombinant human (rh) FSH (Gonal-F) and rhLH were gifts from Serono, and purified hCG (CR-127) was a gift from the National Hormone and Pituitary Programme, NIDDK, NIH, Bethesda, MA, USA. Recombinant human activin A peptide was generously provided by Dr A F Parlow (NIDDK's National Hormone and Pituitary Programme). 8-BrcAMP was purchased from Sigma, staurosporine from Boehringer Mannheim (Mannheim, Germany), and IGF type-1 receptor antibody aIR3 from Oncogene Sciences (Uniondale, NY, USA).

Inhibin $\mathrm{A}$ and $\mathrm{B}$ were measured by specific enzymelinked immunosorbent assay (ELISA) kits (product codes MCA950 KZZ and MCA1312 KZZ respectively; Serotec Ltd, Oxford, Oxon, UK) as described previously (Groome et al. 1990, 1996, Groome \& Lawrence 1991). The detection limit for the assay was reported to be $2 \mathrm{pg} / \mathrm{ml}$ for inhibin A and $15 \mathrm{pg} / \mathrm{ml}$ for inhibin B. Both intraand interassay coefficients of variation were below $10 \%$ and $7 \%$ for inhibin $\mathrm{A}$ and $\mathrm{B}$ respectively. The samples were assayed in duplicate. According to the manufacturer, there is minimal cross reaction with inhibin B or activins in the inhibin $\mathrm{A}$ assay, and about $1 \%$ cross reaction with inhibin $\mathrm{A}$ in the inhibin $\mathrm{B}$ assay. When activin added into the cell culture medium (up to $40 \mathrm{ng} / \mathrm{ml}$ ) was measured with the inhibin A and B assays, no cross reaction could be detected. Differences in the inhibin concentrations between treatment groups were assessed by the MannWhitney test. The level of significance was chosen as $P<0 \cdot 05$. 


\section{Results}

Each experiment was performed with cells derived from the follicles of a single woman, or in some cases with cells pooled from 2-6 women. Both inhibin A and inhibin B secretion was detectable in all conditioned media of cultured human ovarian granulosa-luteal cells. There was considerable variation in the absolute concentrations of both forms of inhibin in the conditioned media of different granulosa cell pools. The mean ( \pm s.E.M.) secretion of inhibin A was $537.9( \pm 131 \cdot 7) \mathrm{pg} / \mathrm{ml} / 24 \mathrm{~h} \quad(n=16$; $n$ means the number of experiments pooled together, each experiment consisted of a single culture with $2-3$ parallel wells), and that of inhibin B $433 \cdot 0( \pm 80 \cdot 4) \mathrm{pg} / \mathrm{ml} / 24 \mathrm{~h}$ $(n=18)$ at the stage when the experiments were performed (7th-11th days of culture). The inhibin $\mathrm{A} / \mathrm{B}$ ratio in the same cultures was $1.24 \pm 0.21$ (mean \pm s.e.M.). As the absolute inhibin values do not have any particular significance in cell culture experiments, and due to the above mentioned considerable variation in the absolute concentrations of the secreted inhibins in different cell pools, the regulation data below are presented as changes compared with the control situation in each experiment. Progesterone was measured in selected conditioned media and its secretion into the medium was about $1500 \mathrm{nmol} / \mathrm{l} / 24 \mathrm{~h}$ at the time the experiments were performed.

Both rhFSH and rhLH increased dose dependently inhibin $\mathrm{A}$ and $\mathrm{B}$ secretion into the culture medium; the maximal effect was reached between 30 and $100 \mathrm{IU} / 1$ (dose-response data not shown). In repeated experiments with cells from separate cell pools rhFSH (30 or $100 \mathrm{IU} / \mathrm{l}$ ) increased inhibin A and B secretion up to $179 \cdot 9 \pm 21 \cdot 5 \%$ and $166 \cdot 7 \pm 27 \cdot 4 \%$ respectively of control (mean \pm s.E.M.; $P<0 \cdot 01, n=8$ for both). rhLH (30 or $100 \mathrm{IU} / 1)$ increased inhibin A and B secretion up to $192 \cdot 4 \pm 14 \cdot 7 \%(P<0 \cdot 05$, $n=4)$ and $139 \cdot 0 \pm 20 \cdot 3 \%(P<0 \cdot 05, n=4)$ respectively of control, and hCG $(100 \mathrm{ng} / \mathrm{ml})$ up to $210 \cdot 1 \pm 53 \cdot 5 \%$ $(P<0 \cdot 01, n=6)$ and $127 \cdot 4 \pm 32 \cdot 1 \%$ (not significant (NS), $n=6)$ respectively of control. 8 -BrcAMP $(100 \mu \mathrm{M})$ increased inhibin A secretion up to $243 \cdot 3 \pm 24 \cdot 5 \%(P<0 \cdot 01$, $n=16)$ and inhibin B secretion up to $132 \cdot 8 \pm 15 \cdot 8 \%$ (NS, $n=16$ ) of control (presented graphically in Fig. 1). In time-course experiments no increase in inhibin secretion was detectable after four hours of hormonal manipulations but after $24 \mathrm{~h}$ rhFSH, rhLH, hCG and 8-BrcAMP had increased inhibin secretion (time-course data not shown).

The protein kinase $\mathrm{C}$ inhibitor staurosporine decreased basal inhibin $\mathrm{B}$ secretion to $49 \cdot 2 \pm 5 \cdot 6 \%$ (mean \pm s.E.M.) $(P<0 \cdot 01, n=7)$ of control, but it did not have any significant effect on inhibin A secretion. Staurosporine also decreased inhibin $\mathrm{B} \quad(P<0 \cdot 05, \quad n=4)$ but not inhibin A secretion in 8-BrcAMP-treated cultures (Fig. 2). FSH-induced inhibin B secretion was also inhibited by staurosporine in two cultures performed (data not shown).

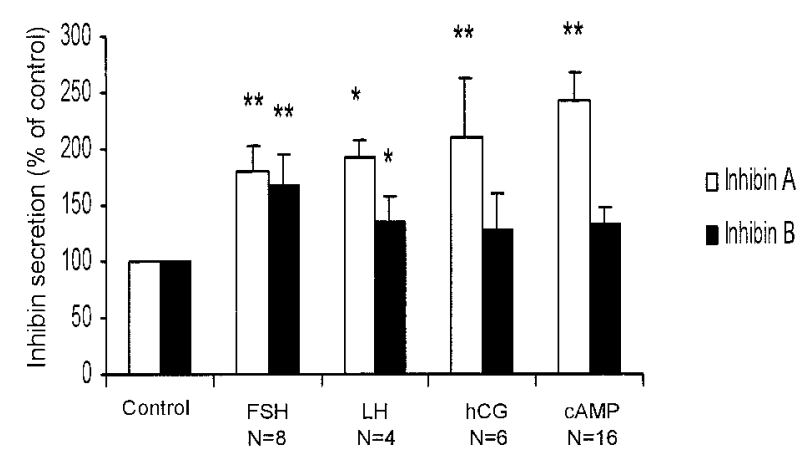

Figure 1 The effects of rhFSH (100 IU/I), rhLH (100 IU/I), hCG $(100 \mathrm{ng} / \mathrm{ml})$ and 8-BrcAMP (cAMP, $100 \mu \mathrm{M})$ on inhibin secretion in cultured human ovarian granulosa-luteal cells during $24 \mathrm{~h}$ of treatment. Means \pm S.E.M. from 4-16 different experiments in each group are shown with the control mean adjusted to $100 . \mathrm{N}=$ the number of experiments pooled in each treatment group. ${ }^{*} P<0 \cdot 05$, ${ }^{* *} P<0.01$ compared with the respective control.

Activin A addition (40 $\mathrm{ng} / \mathrm{ml})$ into the culture medium increased basal inhibin B secretion up to $409 \cdot 2 \pm 61 \cdot 6 \%$ of control (mean \pm S.E.M.; $P<0 \cdot 05 ; n=3$ ) and it further stimulated FSH-induced inhibin B secretion $(P<0 \cdot 05$; $n=3$ ) (Fig. 3). The stimulatory effect of activin A was dose dependent, detectable from 3-10 ng/ml upwards, and reached its maximum between 30 and $100 \mathrm{ng} / \mathrm{ml}$ (doseresponse data not shown). Activin A addition had no effect on inhibin A secretion (Fig. 3).

Addition of the type-1 IGF receptor antibody aIR3 (which blocks the effect of IGFs through the type-1

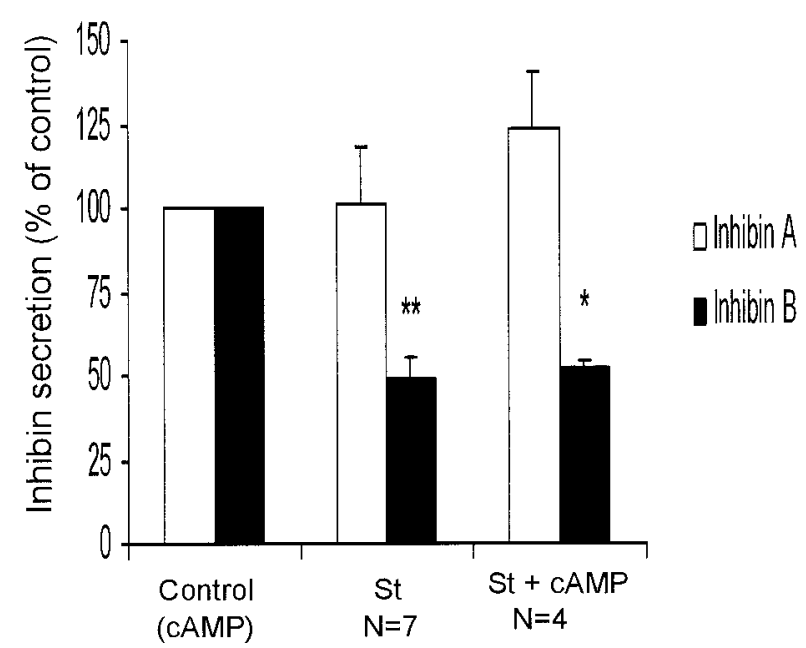

Figure 2 The effect of staurosporine (St, $30 \mathrm{nM}$ ) on basal and 8-BrcAMP-induced (CAMP, $100 \mu \mathrm{M}$ ) inhibin secretion in cultured human granulosa-luteal cells during $48 \mathrm{~h}$ of treatment. Means \pm S.E.M. from 4-7 different experiments in each group are shown with the control mean (both untreated and 8-BrcAMP-treated) adjusted to $100 . N=$ the number of experiments pooled in each treatment group. ${ }^{*} P<0 \cdot 05 ;{ }^{*} P<0 \cdot 01$ compared with the respective control. 


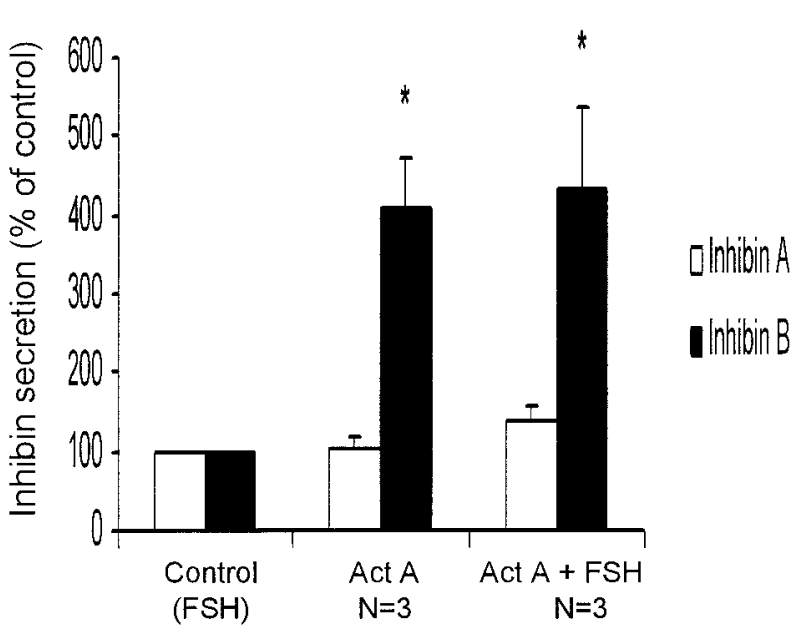

Figure 3 The effect of activin A (Act A, $40 \mathrm{ng} / \mathrm{ml}$ ) on basal, and rhFSH-induced $(100 \mathrm{IU} / \mathrm{I})$ inhibin secretion in cultured human granulosa-luteal cells during $48 \mathrm{~h}$ of treatment. Means \pm S.E.M. from 3 different experiments in each group are shown with the control mean (both untreated and FSH-treated) adjusted to 100. $\mathrm{N}=$ the number of experiments pooled in each treatment group. ${ }^{*} P<0.05$ compared with the respective control.

receptor) into the culture medium decreased inhibin $\mathrm{A}$ secretion to $69 \cdot 5 \pm 3 \cdot 3 \%$ and inhibin $B$ secretion to $49 \cdot 7 \pm 7 \cdot 9 \%$ of control $(P<0 \cdot 01$ for both; $n=5)$. In hCGtreated cultures $\alpha$ IR 3 decreased inhibin A secretion to $71 \cdot 9 \pm 12 \cdot 5 \%$ and inhibin B to $54 \cdot 3 \pm 4 \cdot 0 \%(P<0 \cdot 05$ for both, $n=3$ ) of the secretion detected without $\alpha$ IR3 addition. $\alpha$ IR 3 decreased slightly inhibin $\mathrm{B}$ secretion in 8 -BrcAMP-treated cultures $(P<0 \cdot 05 ; n=5)$, but it had no significant effect on inhibin A secretion (Fig. 4).

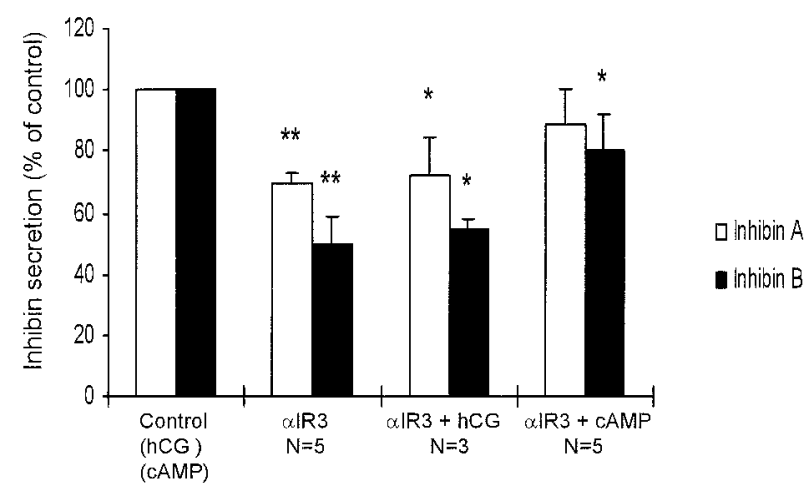

Figure 4 The effect of the type- 1 IGF receptor antibody aIR3 $(1 \mu \mathrm{g} / \mathrm{ml})$ on basal, and hCG- $(100 \mathrm{ng} / \mathrm{ml})$ and 8 -BrcAMP- (cAMP, $100 \mu \mathrm{M})$ regulated inhibin secretion in cultured human granulosaluteal cells during $48 \mathrm{~h}$ of treatment. Means \pm S.E.M. from $3-5$ different experiments in each group are shown with the control mean (untreated, hCG- and 8-BrcAMP-treated) adjusted to 100. $\mathrm{N}=$ the number of experiments pooled in each treatment group. ${ }^{*} P<0 \cdot 05 ;{ }^{*} P<0 \cdot 01$ compared with the respective control.

\section{Discussion}

Previous studies using cultured human granulosa-luteal cells have shown that inhibin $\alpha$ - and $\beta$ A-subunit gene expression is induced by FSH, hCG and cAMP analogs. However, $\beta \mathrm{B}$-subunit mRNA accumulation is not increased by these agents (Erämaa et al. 1994, Tuuri et al. 1996). Gonadotropins mediate their effects on human granulosa-luteal cells via increased cAMP production and protein kinase A activation. In this study rhFSH, rhLH, hCG and 8-BrcAMP increased significantly inhibin A secretion while the stimulatory effect of these agents on inhibin B was less pronounced or insignificant. These data fit well with previous $m R N A$ regulation data; induction of $\alpha$ - and $\beta A$-subunits leads to increased inhibin A production, and the slightly increased inhibin B production can be explained by increased $\alpha$-subunit expression assuming that enough $\beta \mathrm{B}$-subunits are available. Our inhibin $\mathrm{A}$ and B secretion data fit fairly well with those of Muttukrishna et al. (1997) who recently reported gonadotropin-induced inhibin A and B secretion in cultured human ovarian granulosa-luteal cells.

Staurosporine is a relatively specific protein kinase C inhibitor. It reduced basal and gonadotropin-induced inhibin B secretion, suggesting that the protein kinase C-dependent regulatory pathway is important in the regulation of inhibin $\mathrm{B}$ synthesis. To our knowledge there are no convincing data on the effects of protein kinase $\mathrm{C}$ regulators on $\beta \mathrm{B}$-subunit gene expression to explain the mechanism for the clear inhibition of inhibin B secretion caused by staurosporine in these cells. However, protein kinase $\mathrm{C}$ has been reported to be involved in the induction of $\beta$ A-subunit gene expression in human granulosa-luteal cells (Tuuri et al. 1996).

Activin A turned out to be a very potent inducer of inhibin B secretion. A similar effect of activin has been found in cultured rat granulosa cells (Lanuza et al. 1999). Increased inhibin $\mathrm{B}$ secretion can be explained by the activin A-induced $\beta B$-subunit gene expression reported previously (Erämaa et al. 1995). Activin A is produced by human granulosa-luteal cells (Muttukrishna et al. 1997) enabling it to have a physiological autocrine/paracrine role in the regulation of ovarian inhibin production. In our experiments activin A did not increase inhibin A secretion, which is in contrast to rat granulosa cell data (Lanuza et al. 1999), but fits well with the human mRNA data showing no induction of $\alpha$ - or $\beta$ A-subunit gene expression during activin treatment (Erämaa et al. 1995).

IGFs are likely to upregulate inhibin secretion in human granulosa-luteal cells. This hypothesis is supported by the clear inhibition of inhibin secretion by $\alpha$ IR 3 which blocks the IGF-I- and -II-mediated signaling through the type 1 IGF receptor. Previous studies have shown that endogenous IGF-I production is essential for inhibin $\alpha$-subunit expression in rat granulosa cells (Kubo et al. 1998, Li et al. 1998). In addition, IGF-I increased inhibin production by 
cultured rat granulosa cells (Lanuza et al. 1999). We can assume that IGF-II is the main autocrine/paracrine IGF upregulating inhibin synthesis in human ovaries. This assumption is based on the high and gonadotropindependent expression of the IGF-II gene in human ovaries (Voutilainen \& Miller 1987, Voutilainen et al. 1996).

In summary, our data show that gonadotropins via the protein kinase A signal transduction pathway are the main positive regulators of inhibin $\mathrm{A}$ and $\mathrm{B}$ secretion in human granulosa-luteal cells. The protein kinase $\mathrm{C}$ signal transduction pathway seems to be important especially for inhibin B secretion. Locally produced activins are probably important inducers of inhibin B production, and IGFs seem to upregulate both forms of inhibin in human ovaries.

\section{Acknowledgements}

Ms Merja Haukka and Ms Irma Janhunen are thanked for their technical assistance. Recombinant human FSH and LH for in vitro experiments were generously provided by Serono-Nordic (Vantaa, Finland), and activin A peptide (Dr A F Parlow) and hCG (CR-127) by the National Hormone and Pituitary Program, NIDDK, NIH. This study was financially supported by the Academy of Finland, the Finnish Foundation for Pediatric Research, and the Kuopio University Hospital (Research Contract No. 5107 to R V).

\section{References}

Arora DS, Cooke IE, Ganesan TS, Ramsdale J, Manek S, Charnock FM, Groome NP \& Wells M 1997 Immunohistochemical expression of inhibin/activin subunits in epithelial and granulosa cell tumours of the ovary. Journal of Pathology 181 413-418.

Erämaa M, Tuuri T, Hildén K \& Ritvos O 1994 Regulation of inhibin $\alpha$ - and $\beta$ A-subunit messenger ribonucleic acid levels by chorionic gonadotropin and recombinant follicle-stimulating hormone in cultured human granulosa-luteal cells. Journal of Clinical Endocrinology and Metabolism 79 1670-1677.

Erämaa M, Hilden K, Tuuri T \& Ritvos O 1995 Regulation of inhibin/activin subunit messenger ribonucleic acids (mRNAs) by activin A and expression of activin receptor mRNAs in cultured human granulosa-luteal cells. Endocrinology 136 4382-4389.

Findlay JK 1993 An update on the roles of inhibin, activin, and follistatin as local regulators of folliculogenesis. Biology of Reproduction 48 15-23.

Groome NP \& Lawrence M 1991 Preparation of monoclonal antibodies to the beta A subunit of ovarian inhibin using a synthetic peptide immunogen. Hybridoma 10 309-310.

Groome NP, Hancock J, Betteridge A, Lawrence M \& Crawen R 1990 Monoclonal and polyclonal antibodies reactive with the 1-32 amino terminal sequence of the alpha subunit of human $32 \mathrm{~K}$ inhibin. Hybridoma 9 31-42.

Groome NP, Illingworth PJ, O'Brien M, Pai R, Rodger FE, Mather JP \& McNeilly AS 1996 Measurement of dimeric inhibin B throughout the human menstrual cycle. Journal of Clinical Endocrinology and Metabolism 81 1401-1405.
Hsueh AJW, Dahl KD, Vaughan J, Tucker E, Rivier J, Bardin CW \& Vale W 1987 Heterodimers and homodimers of inhibin subunits have different paracrine action in the modulation of luteinizing hormone-stimulated androgen biosynthesis. PNAS 84 5082-5086.

Kubo T, Shimasaki S, Kim H, Li D \& Erickson GF 1998 Activin-induced inhibin $\alpha$-subunit production by rat granulosa cells requires endogenous insulin-like growth factor-I. Biology of Reproduction $\mathbf{5 8} 712-718$.

Lanuza GM, Groome NP, Baranao JL \& Campo S 1999 Dimeric inhibin A and B production are differentially regulated by hormones and local factors in rat granulosa cells. Endocrinology 140 2549-2554.

Li D, Kubo T, Kim H, Shimasaki S \& Erickson GF 1998 Endogenous insulin-like growth factor-I is obligatory for stimulation of rat inhibin $\alpha$-subunit expression by follicle-stimulating hormone. Biology of Reproduction 58 219-225.

Mason AJ, Niall HD \& Seeburg PH 1986 Structure of two human ovarian inhibins. Biochemical and Biophysical Research Communications 28 957-964.

Mather JP, Woodruff TK \& Krummen LA 1992 Paracrine regulation of reproductive function by inhibin and activin. Proceedings of the Society for Experimental Biology and Medicine 201 1-15.

Matzuk MM, Finegold MJ, Su J-GJ, Hsueh AJW \& Bradley A 1992 $\alpha$-Inhibin is a tumour suppressor gene with gonadal specificity in mice. Nature 360 313-319.

Matzuk MM, Kumar TR, Shou W, Coerver KA, Lau AL, Behringer RR \& Finegold MJ 1996 Transgenic models to study the roles of inhibins and activins in reproduction, oncogenesis, and development. Recent Progress in Hormone Research 51 123-154.

Miró F \& Hillier SG 1992 Relative effects of activin and inhibin on steroid hormone synthesis in primate granulosa cells. Journal of Clinical Endocrinology and Metabolism 75 1556-1561.

Muttukrishna S, Groome N \& Ledger W 1997 Gonadotropic control of secretion of dimeric inhibins and activin A by human granulosaluteal cells in vitro. Journal of Assisted Reproduction and Genetics 14 566-574.

Rabinovici J, Spencer SJ, Doldi N, Goldsmith PC, Schwall R \& Jaffe RB 1992 Activin-A as an intraovarian modulator: actions, localization, and regulation of the intact dimer in human ovarian cells. Journal of Clinical Investigation 89 1528-1536.

Roberts VJ, Barth S, el-Roeiy A \& Yen SSC 1993 Expression of inhibin/activin subunits and follistatin messenger ribonucleic acids and proteins in ovarian follicles and the corpus luteum during the human menstrual cycle. Journal of Clinical Endocrinology and Metabolism 77 1402-1410.

Schwall RH, Mason AJ, Wilcox JN, Basset SG \& Zeletznik AJ 1990 Localization of inhibin/activin subunit mRNAs within the primate ovary. Molecular Endocrinology 4 75-79.

Tuuri T, Erämaa M, Van Schaik RHN \& Ritvos O 1996 Differential regulation of inhibin/activin $\alpha$ - and $\beta A$-subunit and follistatin mRNAs by cyclic AMP and phorbol ester in cultured human granulosa-luteal cells. Molecular and Cellular Endocrinology 121 1-10.

Vale W, Rivier C, Hsueh A, Campen C, Meunier H, Bicsak T, Vaughan J, Corrigan A, Bardin W, Sawchenko P, Petraglia F, Yu J, Plotsky P, Spiess J \& Rivier J 1988 Chemical and biological characterization of the inhibin family of protein hormones. Recent Progress in Hormone Research 44 1-34.

Voutilainen R \& Miller WL 1987 Coordinate tropic hormone regulation of mRNAs for insulin-like growth factor II and cholesterol side-chain cleavage enzyme, P450 scc, in human steroidogenic tissues. PNAS 84 1590-1594.

Voutilainen R, Tapanainen J, Chung B-C, Matteson KJ \& Miller WL 1986 Hormonal regulation of P450 scc (20,22-desmolase) and P450c17 (17 $\alpha$-hydroxylase/17,20-lyase) in cultured human granulosa cells. Journal of Clinical Endocrinology and Metabolism 63 202-207.

Voutilainen R, Franks S, Mason HD \& Martikainen H 1996 Expression of insulin-like growth factor (IGF), IGF-binding protein, and IGF receptor messenger ribonucleic acids in normal and 
polycystic ovaries. Journal of Clinical Endocrinology and Metabolism $\mathbf{8 1}$ 1003-1008.

Woodruff TK 1998 Regulation of cellular and system function by activin. Biochemical Pharmacology 55 953-963.

Yamoto M, Minami S, Nakano R \& Kobayashi M 1992

Immunohistochemical localization of inhibin/activin subunits in

human ovarian follicles during the menstrual cycle. Journal of

Clinical Endocrinology and Metabolism 74 989-993.
Ying SY 1988 Inhibins, activins, and follistatins: gonadal proteins modulating the secretion of follicle-stimulating hormone. Endocrine Reviews 9 267-293.

Received 25 October 1999

Revised manuscript received 27 April 2000 Accepted 30 June 2000 